\title{
Biomass Fly Ash Deposition in an Entrained Flow Reactor
}

Laxminarayan, Yashasvi; Jensen, Peter Arendt; Wu, Hao; Jappe Frandsen, Flemming; Sander, Bo; Glarborg, Peter

\section{Published in:}

Proceedings of the Combustion Institute

Link to article, DOI:

10.1016/j.proci.2018.06.039

Publication date:

2019

Document Version

Peer reviewed version

Link back to DTU Orbit

Citation $(A P A)$ :

Laxminarayan, Y., Jensen, P. A., Wu, H., Jappe Frandsen, F., Sander, B., \& Glarborg, P. (2019). Biomass Fly Ash Deposition in an Entrained Flow Reactor. Proceedings of the Combustion Institute, 37(3), 2689-2696. https://doi.org/10.1016/j.proci.2018.06.039

\section{General rights}

Copyright and moral rights for the publications made accessible in the public portal are retained by the authors and/or other copyright owners and it is a condition of accessing publications that users recognise and abide by the legal requirements associated with these rights.

- Users may download and print one copy of any publication from the public portal for the purpose of private study or research.

- You may not further distribute the material or use it for any profit-making activity or commercial gain

- You may freely distribute the URL identifying the publication in the public portal 


\section{Biomass Fly Ash Deposition in an Entrained Flow}

\section{Reactor}

Yashasvi Laxminarayan* ${ }^{\dagger} \dagger$, Peter Arendt Jensen ${ }^{\dagger}$, Hao $\mathrm{Wu}^{\dagger}{ }^{\dagger}$, Flemming Jappe Frandsen ${ }^{\dagger}$, Bo Sander ${ }^{\S}$, Peter Glarborg ${ }^{\dagger}$

$\dagger$ Department of Chemical and Biochemical Engineering, Technical University of Denmark, Søltofts Plads 229, 2800 Kgs. Lyngby, Denmark

$\S$ Ørsted Bioenergy \& Thermal Power A/S, Kraftsværksvej 53, Skærbæk, DK-7000, Fredericia, Denmark

\section{*Corresponding author information}

Name: Yashasvi Laxminarayan

e-mail id: ylax@kt.dtu.dk

Address: Department of Chemical and Biochemical Engineering, Technical University of Denmark, Søltofts Plads 229, 2800 Kgs. Lyngby, Denmark

Colloquium: Solid Fuel Combustion, Stationary Combustion Systems and Control of Greenhouse Gas Emissions 


\begin{abstract}
Fly ash deposition on boiler surfaces is a major operational problem encountered in biomass-fired boilers. Understanding deposit formation, and developing modelling tools, will allow improvements in boiler efficiency and availability. In this study, deposit formation of a model biomass ash species $\left(\mathrm{K}_{2} \mathrm{Si}_{4} \mathrm{O}_{9}\right)$ on steel tubes, was investigated in a lab-scale Entrained Flow Reactor. $\mathrm{K}_{2} \mathrm{Si}_{4} \mathrm{O}_{9}$ was injected into the reactor, to form deposits on an air-cooled probe, simulating deposit formation on superheater tubes in boilers. The influence of flue gas temperature $\left(589-968^{\circ} \mathrm{C}\right)$, probe surface temperature $(300-$ $\left.550{ }^{\circ} \mathrm{C}\right)$, flue gas velocity $(0.7-3.5 \mathrm{~m} / \mathrm{s})$, fly ash flux $\left(10000-40000 \mathrm{~g} / \mathrm{m}^{2} \mathrm{~h}\right)$, and probe residence time (up to $60 \mathrm{~min}$ ) was investigated. The results revealed that increasing flue gas temperature and probe surface temperature increased the sticking probability of the fly ash particles, thereby increasing the rate of deposit formation. However, increasing flue gas velocity resulted in a decrease in the deposit formation rate, due to increased particle rebound. Furthermore, the deposit formation rate increased with probe residence time and fly ash flux. Inertial impaction was the primary mechanism of deposit formation, forming deposits only on the upstream side of the steel tube. A mechanistic model was developed for predicting deposit formation in the reactor. Deposit formation by thermophoresis and inertial impaction was incorporated into the model, and the sticking probability of the ash particles was estimated by accounting for energy dissipation due to particle deformation. The model reasonably predicted the influence of flue gas temperature and fly ash flux on the deposit formation rate.
\end{abstract}

Keywords: biomass, fly ash, deposit formation, fouling, ash sticking probability 


\section{Introduction}

Combustion of biomass for electricity and heat production is a promising solution for reducing net $\mathrm{CO}_{2}$ emissions. Denmark is planning to phase out coal by 2030, with intentions to replace it with biomass in pulverized fuel-fired power plants [1]. However, the inorganic content in biomass causes several operational problems, including increased deposition of chemically aggressive ash species on boiler surfaces. Ash deposits hinder heat transfer to the steam cycle, thereby reducing boiler efficiency, causing corrosion of boiler surfaces, and blocking flue gas channels in severe cases, causing unscheduled boiler shut-downs [2]. Therefore, reducing deposit formation is essential for maximizing boiler efficiency and availability.

Inorganic species in the flue gas may occur as vapors, submicron aerosol particles, and larger fly ash particles. The vapor species may undergo heterogeneous condensation on heat transfer surfaces. Deposition of submicron aerosol particles may occur via thermophoresis, Brownian motion or eddy diffusion [3]. Deposition of larger fly ash particles primarily occurs via inertial impaction, and subsequent particle sticking, which is dependent on the collision efficiency and sticking probability of the fly ash particles to boiler surfaces [3]. However, quantification of sticking probability has been a challenge.

Simple sticking models correlate the sticking probability with the viscosity of the particles and the deposit surface [4]. When the ash composition is dominated by alkali salts, the sticking probability may be expressed as a function of the melt fraction of the particle/deposit surface [3]. In the low temperature region of the boilers, where the ash predominantly exists as viscoelastic particles, deposition can be described using detailed models, accounting for energy dissipation due to particle deformation [5]. Such models define a critical velocity of the incoming particle, such that deposition occurs if the particle velocity is lower than the critical velocity. A comprehensive review of ash sticking and rebound criteria may be found in literature [6].

Several experimental investigations quantifying deposit formation in full-scale grate-fired $[7,8]$ and suspension-fired [9-12] boilers, as well as pilot-scale and lab-scale studies [13-18], have been reported. 
However, a comprehensive fundamental investigation, quantifying the effect of operating conditions and ash chemistry on deposit build-up, at well-defined conditions relevant for biomass-fired boilers, is lacking.

In this study, ash deposition on steel tubes in a laboratory Entrained Flow Reactor (EFR) was quantified, at conditions simulating full-scale biomass-fired boilers. Model biomass fly ash, comprised of $\mathrm{K}_{2} \mathrm{Si}_{4} \mathrm{O}_{9}$, was injected into the reactor, to form deposits on an air-cooled probe. The influence of flue gas temperature, probe surface temperature, flue gas velocity, fly ash flux, and probe residence time was investigated. Furthermore, a mechanistic model was developed to predict deposit formation in the reactor.

\section{Experimental Section}

\subsection{Materials}

Experiments were carried out with amorphous $\mathrm{K}_{2} \mathrm{Si}_{4} \mathrm{O}_{9}$ (Alfa Aesar, CAS number: 1312-76-1). The majority of biomass fly ashes and deposits contain significant quantities of amorphous materials $[10,19,20]$, including silicates $[2,21]$, characterized by their viscoelastic behavior, justifying the use of $\mathrm{K}_{2} \mathrm{Si}_{4} \mathrm{O}_{9}$ for experimental analysis. Additionally, biomass fly ash deposits may contain alkali metal compounds such as $\mathrm{KCl}$ and $\mathrm{K}_{2} \mathrm{SO}_{4}$ [21]. The influence of fly ash composition on deposit formation has been investigated in a subsequent study [22].

The $\mathrm{K}_{2} \mathrm{Si}_{4} \mathrm{O}_{9}$ had a volume-median particle diameter $\left(\mathrm{D}_{50}\right)$ of $62.3 \mu \mathrm{m}\left(\mathrm{D}_{10}=7.31 \mu \mathrm{m}, \mathrm{D}_{90}=272 \mu \mathrm{m}\right.$, dry basis). Further details on the particle size distribution may be found in the supplemental material (Figure S.1). However, it should be noted that fly ash in boilers typically forms a bimodal particle size distribution, containing submicron particles, as well as larger particles [3]. $\mathrm{K}_{2} \mathrm{Si}_{4} \mathrm{O}_{9}$ was subjected to Differential Scanning Calorimetry (DSC), revealing that $\mathrm{K}_{2} \mathrm{Si}_{4} \mathrm{O}_{9}$ forms a glass phase at $650{ }^{\circ} \mathrm{C}$, after which the viscosity of $\mathrm{K}_{2} \mathrm{Si}_{4} \mathrm{O}_{9}$ decreases with increasing temperature [23].

\subsection{Experimental setup}

The EFR setup consisted of a gas supply system, a screw feeder for injecting solids, a gas preheater, a $2 \mathrm{~m}$ long electrically heated furnace (inner diameter $=80 \mathrm{~mm}$ ), and a fly ash deposition system comprising 
of a steel tube mounted on an air-cooled probe. A schematic representation of the setup is shown in Figure 1. A detailed description of the EFR may be found in previously published literature [24,25,22].

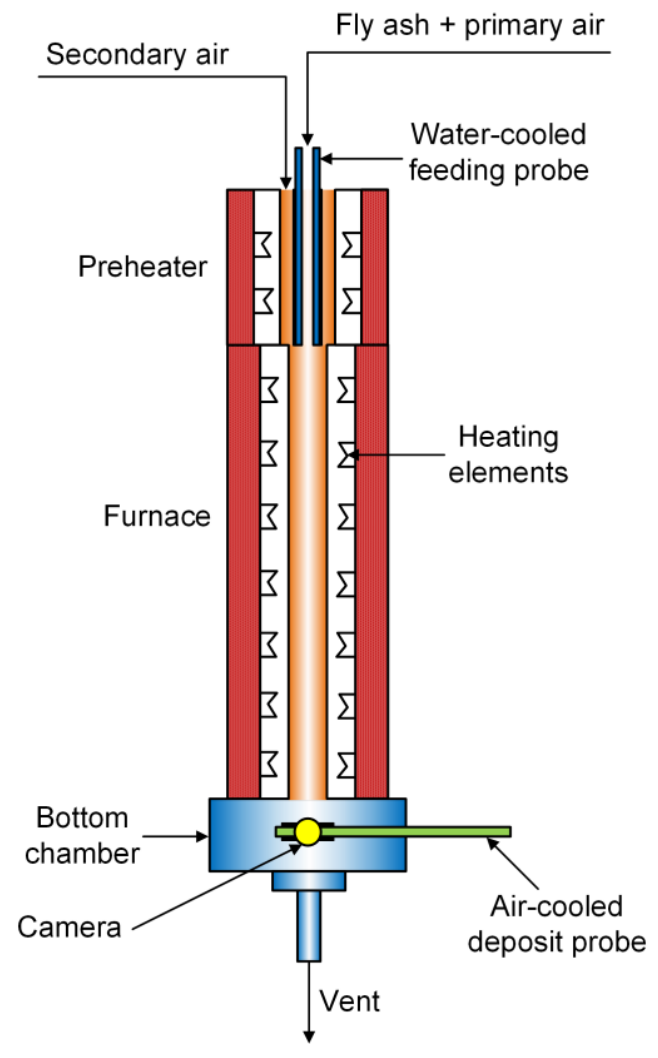

Figure 1. Schematic representation of the Entrained Flow Reactor.

$\mathrm{K}_{2} \mathrm{Si}_{4} \mathrm{O}_{9}$ particles were mixed with primary air, and fed into the furnace, together with preheated secondary air. The walls of the furnace could be heated up to $1450^{\circ} \mathrm{C}$. It should be noted that the particle and gas temperatures in the furnace might be slightly lower than the temperature of the furnace walls.

After the furnace, the entrained flow entered a bottom chamber, where the $\mathrm{K}_{2} \mathrm{Si}_{4} \mathrm{O}_{9}$ particles formed deposits on a steel tube (type 316), simulating deposit formation on the first row of platen superheater tubes in boilers. For each experiment, the steel tubes were used as received, without any pre-oxidization. The steel tube, with an outer diameter of $10 \mathrm{~mm}$, a thickness of $1 \mathrm{~mm}$, and a length of $140 \mathrm{~mm}$, was mounted on a retractable annular cooling probe (diameter of $8 \mathrm{~mm}$ ), as shown in Figure 2. 


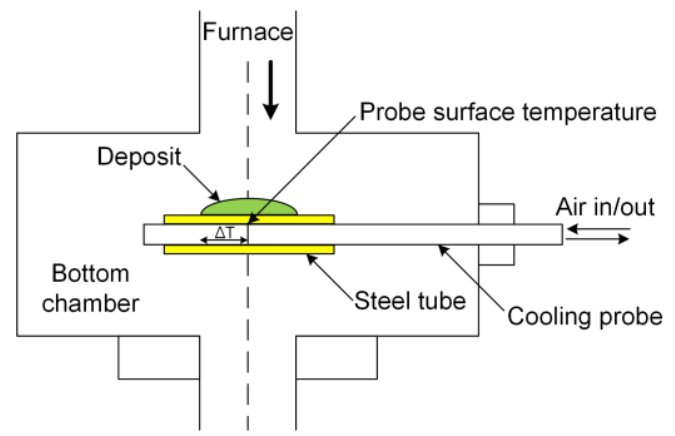

Figure 2. Bottom chamber of the EFR. Deposits are formed on the steel tube mounted on the probe.

The temperature measured between the outer surface of the cooling probe and the inner surface of the steel tube, at the axial centerline of the reactor (referred to as probe surface temperature, see Figure 2), was controlled electronically. The cooling probe surface temperature is analogous to steam temperature in boilers. A horizontal temperature gradient $(\Delta \mathrm{T}$, see Figure 2$)$, of typically $50{ }^{\circ} \mathrm{C}$, was present along the cooling probe. The bottom chamber of the EFR was water-cooled, resulting in a decrease in the flue gas temperature. Therefore, the flue gas temperature in the bottom chamber was measured by replacing the cooling probe with a suction pyrometer.

The fly ash deposition process was recorded by a high-speed camera, mounted on a port in the bottom chamber (see Figure 1). After deposit formation for a specified duration, the probe was retracted, and the deposit was removed and weighed.

\subsection{Experimental conditions}

Baseline experiments were performed at a furnace temperature of $1100{ }^{\circ} \mathrm{C}$, resulting in a flue gas temperature of $781{ }^{\circ} \mathrm{C}$ near the probe, a probe surface temperature of $475^{\circ} \mathrm{C}$, a flue gas velocity of $1 \mathrm{~m} / \mathrm{s}$ (at the furnace temperature), a fly ash flux of $20400 \mathrm{~g} / \mathrm{m}^{2} \mathrm{~h}$, corresponding to a fly ash concentration of $26.57 \mathrm{~g} / \mathrm{Nm}^{3}$, using pure $\mathrm{K}_{2} \mathrm{Si}_{4} \mathrm{O}_{9}$ for $15 \mathrm{~min}$. In other experiments, the flue gas temperature was varied from 589 to $968^{\circ} \mathrm{C}$, the probe surface temperature from 300 to $550{ }^{\circ} \mathrm{C}$, the flue gas velocity from 0.7 to $3.5 \mathrm{~m} / \mathrm{s}$, the fly ash flux from 10000 to $40000 \mathrm{~g} / \mathrm{m}^{2} \mathrm{~h}$, with probe residence times of up to $60 \mathrm{~min}$.

Typical superheater steam temperatures in biomass-fired boilers range from $440-580{ }^{\circ} \mathrm{C}$, while the flue gas temperatures in the superheater/tube bank region range from $580-1300{ }^{\circ} \mathrm{C}[9,20,26,27]$. The 
flue gas velocity in full-scale boilers ranges from $4-8 \mathrm{~m} / \mathrm{s}$ [3,9]. However, lower gas velocities were adopted during the experiments in order to maintain a similar Stokes number $(\approx 1)$. The typical fly ash flux in biomass boilers varies from 10000 to $60000 \mathrm{~g} / \mathrm{m}^{2} \mathrm{~h}$ [20]. However, the corresponding fly ash concentrations in the experiments $\left(13-53 \mathrm{~g} / \mathrm{Nm}^{3}\right)$, are higher than the typical fly ash concentrations in full-scale biomass-fired boilers $\left(1-6 \mathrm{~g} / \mathrm{Nm}^{3}\right)$.

\section{Deposit Formation Model}

A mechanistic deposit formation model was developed to simulate deposit formation in the reactor. The model incorporated deposit formation by thermophoresis and inertial impaction of $\mathrm{K}_{2} \mathrm{Si}_{4} \mathrm{O}_{9}$ particles, while deposit formation by condensation was neglected due to the absence of vapor species in the gas phase.

$\frac{d m(t, \theta)}{d t}=\dot{T}(t, \theta)+\dot{I}(t, \theta)$

where $m$ is the mass of the deposit $(\mathrm{kg}), t$ is the time ( $\mathrm{sec})$, and $\theta$ is the angular position (radians).

The rate of deposit formation by thermophoresis $(\dot{T}(t, \theta))$ was described using Equation 2 [28].

$\dot{T}(t, \theta)=u_{T}(\theta) \cdot C \cdot s(\theta)$

where $u_{T}$ is the thermophoretic velocity $(\mathrm{m} / \mathrm{s}), C$ is the concentration of $\mathrm{K}_{2} \mathrm{Si}_{4} \mathrm{O}_{9}\left(\mathrm{~kg} / \mathrm{m}^{3}\right)$, and $s$ is the surface area of the deposit $\left(\mathrm{m}^{2}\right)$.

The rate of deposit formation by inertial impaction $\dot{I}(t, \theta)$ was described using Equation 3 [3].

$\dot{I}=u_{g} \cdot C \cdot \eta_{I}(\theta) \cdot \eta_{s}(\theta) \cdot s(\theta)$

where $u_{g}$ is the gas velocity $(\mathrm{m} / \mathrm{s}), \eta_{I}$ is the local collision efficiency of each particle, and $\eta_{s}$ is the sticking probability of the ash particles. Since the $\mathrm{K}_{2} \mathrm{Si}_{4} \mathrm{O}_{9}$ particles are viscoelastic in nature, the sticking probability of ash particles was estimated by accounting for energy dissipation due to particle deformation. The critical velocity of the incoming particles $\left(u_{p, c r i t}\right)$ was calculated [5], such that 
$\eta_{s}= \begin{cases}0 & u_{p} \cdot \sin \left(\alpha_{\text {impact }}\right)>u_{p, \text { crit }} \\ 1 & u_{p} \cdot \sin \left(\alpha_{\text {impact }}\right) \leq u_{p, \text { crit }}\end{cases}$

where $u_{p}$ is the particle velocity ( $\left.\mathrm{m} / \mathrm{s}\right)$ and $\alpha_{\text {impact }}$ is the angle of impaction (radians).

The critical velocity of the incoming particle is a function of the particle diameter $\left(d_{p}\right)$, particle density $\left(\rho_{p}\right)$, interface energy (surface tension) $(\Gamma)$ and equivalent Young's modulus $(E)$ [29].

$$
\begin{aligned}
& u_{p, c r i t}=\frac{\left(\frac{2 \Gamma}{d_{p}}\right)^{5 / 6}}{\left(\rho_{p}^{3} E^{2}\right)^{1 / 6}} \\
& \frac{1}{E}=\frac{1-v_{\text {particle }}^{2}}{E_{\text {particle }}}+\frac{1-v_{\text {deposit }}^{2}}{E_{\text {deposit }}}
\end{aligned}
$$

where $v$ is the Poisson's ratio. The Young's modulus was estimated as $E=A \cdot \exp (-B T)$, where $A$ and $B$ are empirical constants obtained from literature [30].

Furthermore, the model incorporated heat transfer across the deposit layer and the steel tube, as described by Equation 7 .

$$
\frac{k_{\text {tube }}}{\delta_{\text {tube }}}\left(T_{\text {tube }}-T_{\text {probe }}\right)=\frac{k_{\text {deposit }}}{\delta_{\text {deposit }}}\left(T_{\text {deposit }}-T_{\text {tube }}\right)=h_{\text {gd }}\left(T_{\text {gas }}-T_{\text {deposit }}\right)+\varepsilon \sigma\left(T_{\text {gas }}^{4}-T_{\text {deposit }}^{4}\right)
$$

$T_{\text {gas }}$ is the gas temperature, whereas $T_{\text {deposit }}, T_{\text {tube }}$, and $T_{\text {probe }}$ are the temperatures at the surface of the deposit, steel tube and probe (K). $k, \delta, h, \varepsilon$, and $\sigma$ refer to the thermal conductivity (W/mK), thickness (m), heat transfer coefficient $\left(\mathrm{W} / \mathrm{m}^{2} \mathrm{~K}^{1}\right)$, emissivity, and Stefan Boltzmann constant $\left(\mathrm{W} / \mathrm{m}^{2} \mathrm{~K}\right)$.

The particles were assumed to be isothermal, with the corresponding heat transfer equation described in Equation 8.

$\rho_{p}\left(\frac{\pi}{6} d_{p}^{3}\right) C_{p} \frac{d T_{\text {particle }}}{d t^{\prime}}=h_{g p}\left(\pi d_{p}^{2}\right)\left(T_{g a s}-T_{\text {particle }}\right)+\varepsilon \sigma\left(\pi d_{p}^{2}\right)\left(T_{g a s}^{4}-T_{\text {particle }}^{4}\right)$ 
$\rho_{p}, C_{p}, d_{p}, T_{\text {particle }}$ and $t^{\prime}$ refer to the particle density $\left(\mathrm{kg} / \mathrm{m}^{3}\right)$, specific heat capacity $(\mathrm{J} / \mathrm{kgK})$, diameter

$(\mathrm{m})$, temperature $(\mathrm{K})$ and residence time $(\mathrm{s})$.

It was assumed that the particles in the furnace were perfectly entrained in the gas flow, resulting in equal particle and gas velocities. The terminal velocity of the $\mathrm{K}_{2} \mathrm{Si}_{4} \mathrm{O}_{9}$ particles was estimated to be $2 \%$ of the gas velocity, using the Wen and Yu drag model [31], justifying the aforementioned assumption.

Further details on the model, and equations used for estimating physical properties, may be found in the supplemental material and previously published literature $[5,19,22]$.

\section{Results and Discussion}

\subsection{Effect of Flue Gas Temperature}

The effect of flue gas temperature on deposit formation rate is shown in Figure 3. It was observed that the deposit formation rate increased with increasing flue gas temperature at the investigated conditions. Visual observations of the formed deposits (see Figure 3) revealed that deposits were formed only on the upstream side of the steel tube, suggesting that $\mathrm{K}_{2} \mathrm{Si}_{4} \mathrm{O}_{9}$ deposition occurred primarily via inertial impaction. Studies on deposit formation in full-scale pulverized biomass-fired boilers have also identified inertial impaction as the primary mechanism of deposit formation [3,9,21]. Increasing the flue gas temperature decreased the viscosity/Young's modulus of the $\mathrm{K}_{2} \mathrm{Si}_{4} \mathrm{O}_{9}$ particles, thereby resulting in stickier particles, and increasing deposit formation via inertial impaction. The experimental results were reproducible with a relative standard error of $4 \%$, based on 5 repetitions of baseline experiments.

The experimental results agree with full-scale investigations [9], where increasing flue gas temperatures led to increased deposit formation. Furthermore, it was observed that increasing the flue gas temperature in the experiments resulted in increased adhesion strength of the deposits to the steel tube, as indicated by previous studies [23]. Deposit shedding was not observed in any of the reported experiments. 
The deposit formation model was able to predict the influence of flue gas temperature on the observed deposit formation rates with an accuracy $\left(\mathrm{R}^{2}\right)$ of $94 \%$ (see Figure 3), suggesting a fairly accurate representation of the sticking probability of the fly ash particles.

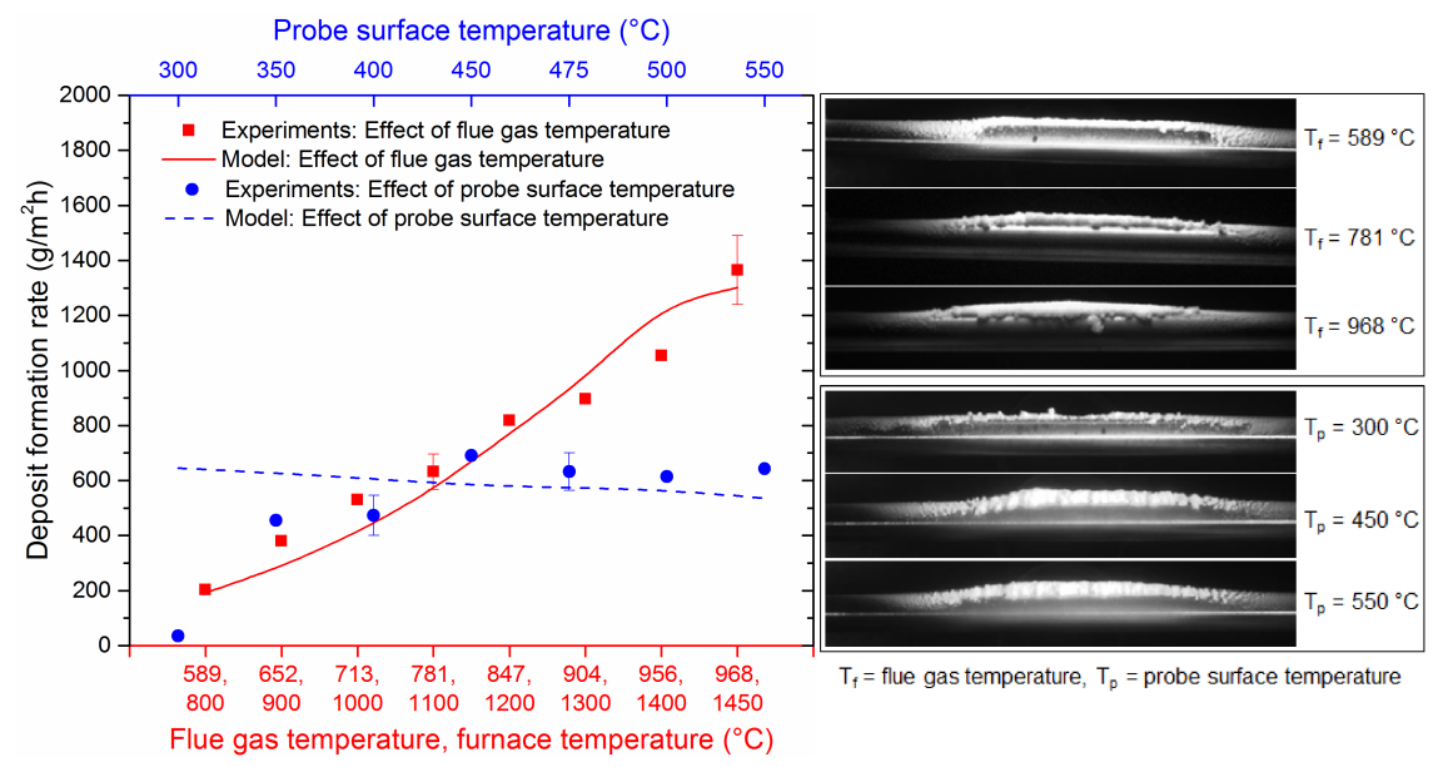

Figure 3. Effect of flue gas temperature and probe surface temperature on the deposit formation rate. Experiments performed with $\mathrm{K}_{2} \mathrm{Si}_{4} \mathrm{O}_{9}$ with a median particle size of $62.3 \mu \mathrm{m}$, mean gas velocity of $1 \mathrm{~m} / \mathrm{s}$, fly ash flux of $20400 \mathrm{~g} / \mathrm{m}^{2} \mathrm{~h}$ for $15 \mathrm{~min}$. Flue gas temperature during variation of probe surface temperature $=781{ }^{\circ} \mathrm{C}$. Probe surface temperature during variation of flue gas temperature $=475^{\circ} \mathrm{C}$. Images captured at the end of the experiments.

\subsection{Effect of Probe Surface Temperature}

Figure 3 also shows the effect of probe surface temperature on the deposit formation rate. It was observed that increasing the probe surface temperature from $300{ }^{\circ} \mathrm{C}$ to $450{ }^{\circ} \mathrm{C}$ increased the deposit formation rate at the investigated conditions. However, increasing the probe surface temperature from 450 $-550^{\circ} \mathrm{C}$ did not influence the rate of deposit formation significantly.

Increasing the probe surface temperature increased the temperature at the surface of the deposit, thereby decreasing the corresponding viscosity/Young's modulus. This resulted in an increased sticking probability of the deposit surface, causing increased deposit formation. However, quantification of the 
temperature at the surface of the deposit would aid in understanding the observed effect of probe surface temperature on the rate of deposit formation.

The results suggest that increasing steam temperatures in boilers might increase deposit formation. However, above a certain steam temperature, determined by the thermal properties of the deposit, a further increase in the steam temperature might not influence the rate of deposit formation. The results concur with a previous investigation [14], where varying probe surface temperatures from $475-650{ }^{\circ} \mathrm{C}$ had a negligible effect on the deposition rate of peat and straw. Nevertheless, it should be noted that high steam temperatures might lead to severe corrosion of the superheater tubes in boilers [27].

The model was unable to accurately predict the influence of probe surface temperature (see Figure 3), especially from $300-400{ }^{\circ} \mathrm{C}$, suggesting that the sticking probability of the deposit surface requires a more accurate representation in the model. Furthermore, the deviations may have emanated from the heat transfer equations in the model, which do not account for the decrease in local gas temperatures induced by the cooling probe, especially when the probe surface temperature is maintained at $300{ }^{\circ} \mathrm{C}$. CFD simulations of the deposit formation process in the EFR may provide more accurate model predictions. The model predicted a relatively linear decrease in the deposit formation rate with increasing probe surface temperature, due to a decrease in the estimated thermophoretic deposition with reducing temperature gradients in the thermal boundary layer.

\subsection{Effect of Mean Flue Gas Velocity}

Figure 4 shows the effect of mean flue gas velocity on the deposit formation rate for flue gas temperatures of 781 and $968^{\circ} \mathrm{C}$. At a flue gas temperature of $781{ }^{\circ} \mathrm{C}$, it was observed that increasing the flue gas velocity from $0.7-3 \mathrm{~m} / \mathrm{s}$ reduced the deposit formation rate, with a sharp decrease observed between $1-1.6 \mathrm{~m} / \mathrm{s}$. However, at a flue gas temperature of $968{ }^{\circ} \mathrm{C}$, the deposit formation rate remained relatively constant from $1-3 \mathrm{~m} / \mathrm{s}$, and decreased in value from $3-3.5 \mathrm{~m} / \mathrm{s}$. Furthermore, it was observed that the thickness of the formed deposits decreased with increasing mean flue gas velocity (see Figure 4). 
Increasing the flue gas velocity, and thereby the particle velocity, increases the kinetic energy of the impacting particles. If the particle velocity exceeds the critical velocity of impaction, the particle is unable to dissipate its kinetic energy, and rebounds from the deposit after impaction. The critical velocity is a function of the particle size and temperature-dependent particle properties. Nevertheless, a relatively sharp decrease in the deposit formation rate with increasing gas velocity was observed, which may be attributed to the fact that the particles with the largest diameter and mass have the lowest critical velocity. Furthermore, the experimental observations suggest that the critical velocity of the $\mathrm{K}_{2} \mathrm{Si}_{4} \mathrm{O}_{9}$ particles increased with increasing temperature at the investigated conditions.

The model predicted a gradual decrease in the deposit formation rate with increasing flue gas velocity (see Figure 4), with an accuracy $\left(\mathrm{R}^{2}\right)$ of $38 \%$. However, the model was unable to predict the sharp decrease in deposit formation rate at $1 \mathrm{~m} / \mathrm{s}$ and $781{ }^{\circ} \mathrm{C}$, and at $3 \mathrm{~m} / \mathrm{s}$ and $968^{\circ} \mathrm{C}$, probably because the model assumed a uniform plug flow in the furnace. Furthermore, agglomeration of particles in the furnace/screw feeder have not been accounted for in the model.

At baseline conditions, the critical velocity predicted by the model varied from $0.23-1.4 \mathrm{~m} / \mathrm{s}$ for particle diameters from $10-100 \mu \mathrm{m}$. These values agree with previous investigations, where the critical velocity varied from $0.1-1.2 \mathrm{~m} / \mathrm{s}$ for particle diameters from $10-100 \mu \mathrm{m}[32-35]$. 


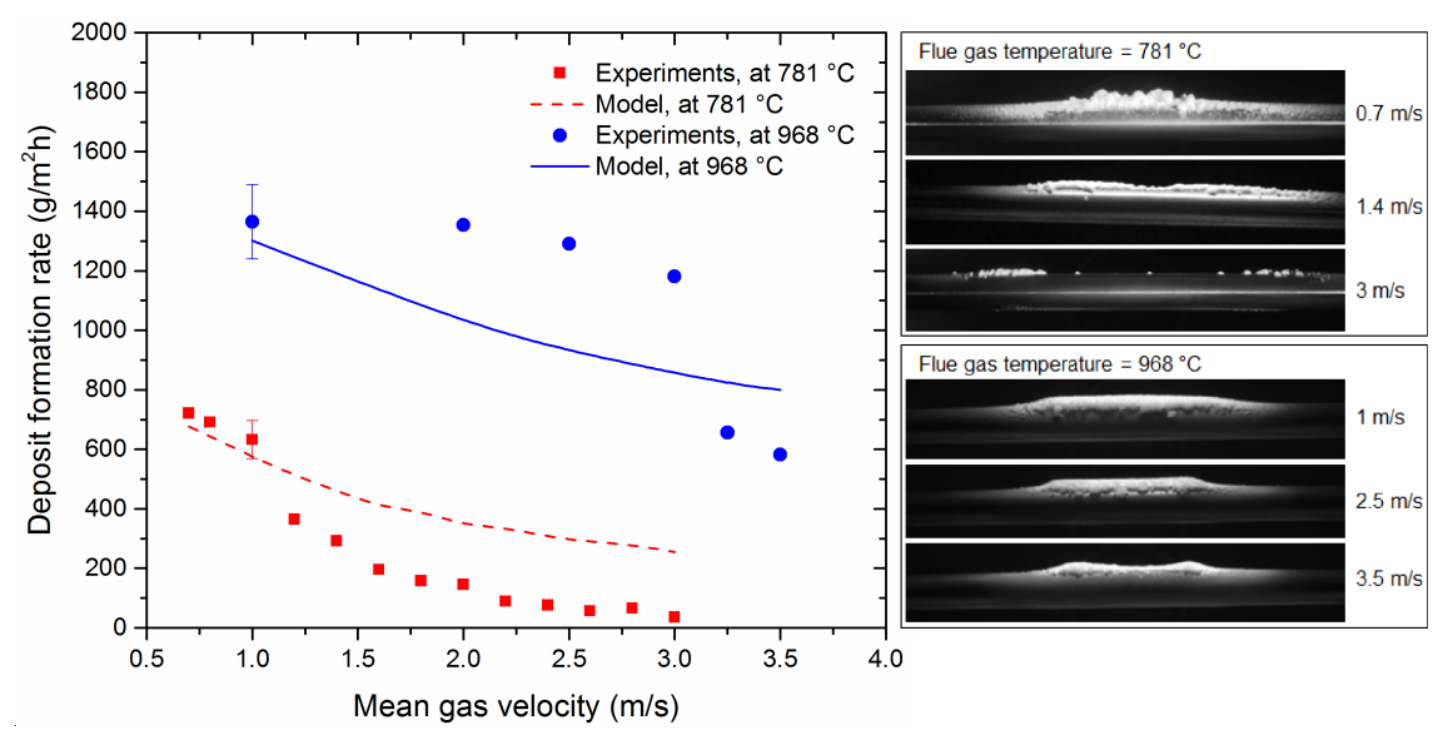

Figure 4. Effect of mean gas velocity on the deposit formation rate. Experiments performed with $\mathrm{K}_{2} \mathrm{Si}_{4} \mathrm{O}_{9}$ with a median particle size of $62.3 \mu \mathrm{m}$, probe surface temperature of $475^{\circ} \mathrm{C}$, fly ash flux of $20400 \mathrm{~g} / \mathrm{m}^{2} \mathrm{~h}$ for $15 \mathrm{~min}$. Images captured at the end of the experiments.

\subsection{Effect of Probe Residence Time}

The effect of probe residence time on deposit formation rate can be seen in Figure 5. The deposit formation rate increased with time up to $30 \mathrm{~min}$, at the investigated conditions. However, further increase in time did not significantly influence the deposit formation rate.

As the deposit grew in size, the temperature at the surface of the deposit increased, thereby increasing the sticking probability of the deposit surface. Therefore, the fraction of impacting particles undergoing deposition increased over time. However, the growth rate of the deposit remained constant after 30 min of deposition. Further investigation, quantifying the temperature history of the deposit surface, is required to completely understand the deposit formation process. Nevertheless, the results highlight the importance of a sticky surface for deposit build-up via inertial impaction. The results are consistent with the experiments in Section 4.2, suggesting that the deposit formation rate may not further increase above a certain temperature at the surface of the deposit.

The model predicted a relatively linear increase in the deposit formation rate with time (see Figure 5), with an accuracy $\left(\mathrm{R}^{2}\right)$ of $39 \%$. This increase may be attributed to the increasing local collision efficiency 
of the incoming particles with increasing deposit thickness. However, the model is not able to predict the saturation in deposit formation rate after $30 \mathrm{~min}$, probably due to an inaccurate representation of the sticking probability of the deposit surface and/or the heat transfer model.

Due to the high temperatures at the deposit surface, sintered deposits could be observed for experiments performed longer than $30 \mathrm{~min}$. Furthermore, natural shedding events were observed only when experiments longer than 60 min were conducted. The large deposits were unstable, breaking away from the steel tube at the deposit-tube interface. A video of deposit formation and shedding on the steel tube can be found in the supplemental material (Video S1), or accessed at youtu.be/gLSHd8fAZo0. The results concur with previous investigations [12,23], establishing debonding as the dominant mechanism of deposit shedding in boilers.

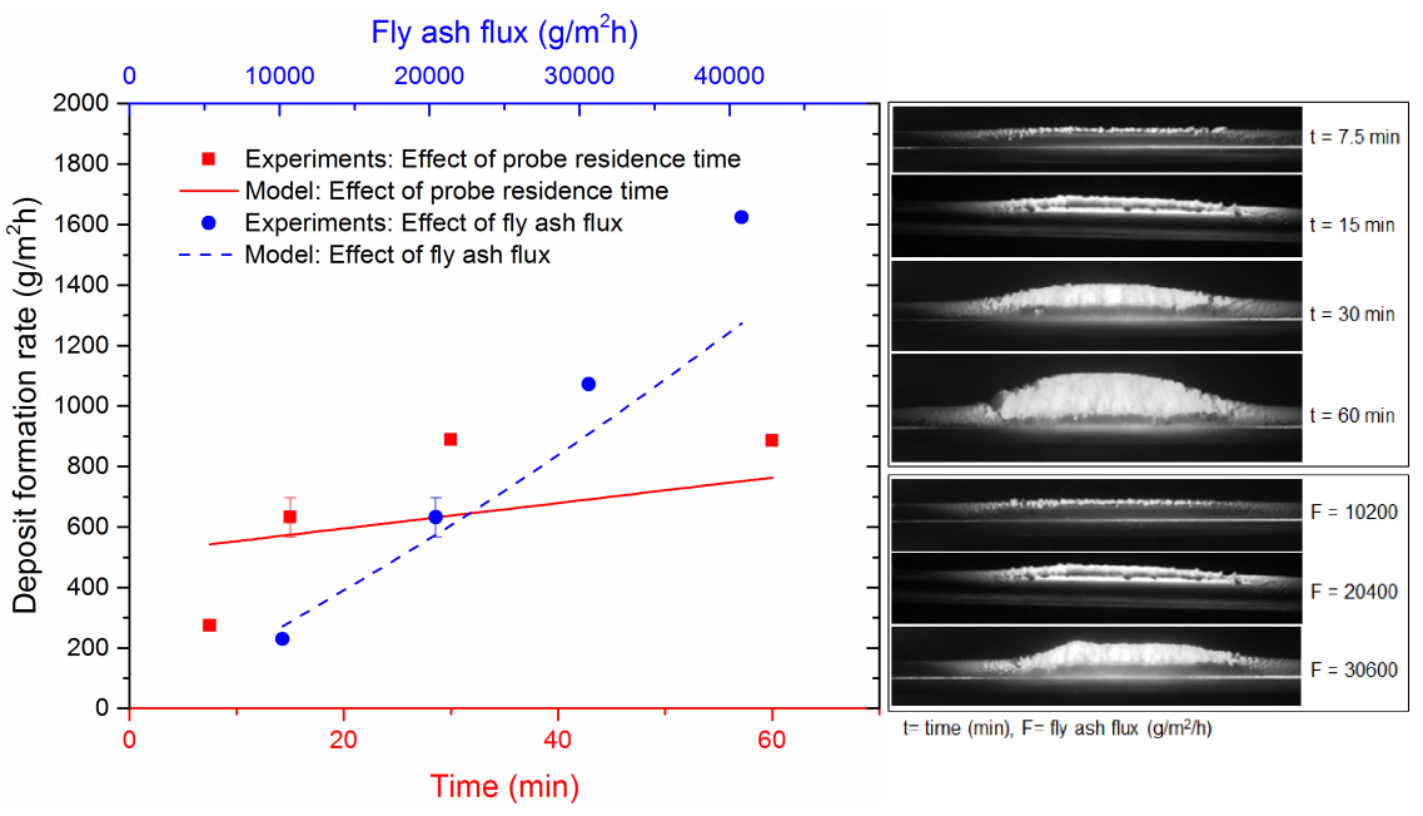

Figure 5. Effect of time and fly ash flux on the deposit formation rate. Experiments performed with $\mathrm{K}_{2} \mathrm{Si}_{4} \mathrm{O}_{9}$ with a median particle size of $62.3 \mu \mathrm{m}$, flue gas temperature of $781^{\circ} \mathrm{C}$, probe surface temperature of $475{ }^{\circ} \mathrm{C}$, and mean gas velocity of $1 \mathrm{~m} / \mathrm{s}$. Fly ash flux during variation of time $=20400 \mathrm{~g} / \mathrm{m}^{2} \mathrm{~h}$. Time during variation of fly ash flux $=15 \mathrm{~min}$. Images captured at the end of the experiments. 


\subsection{Effect of Fly Ash Flux}

The effect of fly ash flux on deposit formation rate can be observed in Figure 5. The deposit formation rate increased linearly with increasing ash flux at the investigated conditions. Increasing ash flux increased the total number of particles impacting the steel tube, thereby resulting in a corresponding increase in the deposit formation rate. The results agree with previous full-scale investigations [7], which indicated a linear increase in the rate of deposit formation via inertial impaction with increasing ash flux.

The model was able to predict the increase in deposit formation rate with increasing ash flux, with an accuracy $\left(\mathrm{R}^{2}\right)$ of $86 \%$. However, the slightly smaller slope of the model predictions may be attributed to an inaccurate representation of the sticking probability of the deposit surface.

\section{Conclusions}

The deposit formation of $\mathrm{K}_{2} \mathrm{Si}_{4} \mathrm{O}_{9}$ on an air-cooled steel tube was investigated in a laboratory-scale Entrained Flow Reactor.

The results revealed that increasing the flue gas temperature from $589-968^{\circ} \mathrm{C}$, and the probe surface temperature from $300-450{ }^{\circ} \mathrm{C}$, increased the deposit formation rate. However, varying the probe surface temperature from $450-550{ }^{\circ} \mathrm{C}$ did not influence the deposit formation rate significantly, at the investigated conditions. Furthermore, increasing flue gas velocity from $0.7-3.5 \mathrm{~m} / \mathrm{s}$ resulted in a decrease in the rate of deposit formation.

The deposit formation rate increased with probe residence time. However, the growth rate of the deposit was constant after 30 min at the investigated conditions. Furthermore, increasing fly ash flux resulted in a linear increase in the deposit formation rate. Inertial impaction was observed to be the primary mechanism of deposit formation, forming deposits only on the upstream side of the steel tube.

A mechanistic model was developed to predict deposit formation in the reactor. The model was able to reasonably predict the influence of flue gas temperature and fly ash flux, suggesting that accounting for energy dissipation due to particle deformation, for predicting the sticking probability of incoming ash 
particles, seems to be fairly successful in predicting the influence of changes in local conditions on the deposit formation process. However, the model was unable to accurately predict the influence of probe surface temperature, gas velocity and probe residence time. Improvements in the prediction of the sticking probability of the deposit surface, as well as CFD simulations of the deposit formation process in the reactor, are desirable to improve model predictions.

The obtained results provide an improved understanding of $\mathrm{K}_{2} \mathrm{Si}_{4} \mathrm{O}_{9}$ deposit formation in boilers, describing the influence of operating conditions on deposit growth. Furthermore, the experimental data may be used to develop novel sticking criteria to predict deposit growth in full-scale boilers. 


\section{Acknowledgements}

This work is part of the project, 'Flexible use of Biomass on PF fired power plants', funded by Energinet through the ForskEL program, Ørsted and DTU.

\section{References}

[1] The Danish Government, Our Future Energy, ISBN: 978-87-7844-915-3, 2011.

[2] F. Frandsen. Ash formation, deposition and corrosion when utilizing straw for heat and power production. Technical University of Denmark, Lyngby, Denmark, 2010, p. 341.

[3] H. Zhou, P.A. Jensen, F.J. Frandsen, Fuel 86 (10-11) (2007) 1519-1533.

[4] P.M. Walsh, A.N. Sayre, D.O. Loehden, L.S. Monroe, J.M. Beér, A.F. Sarofim, Prog. Energy Combust. Sci. 16 (4) (1990) 327-345.

[5] S.B. Hansen, P.A. Jensen, F.J. Frandsen, B. Sander, P. Glarborg, Energy Fuels 31 (3) (2017) 27712789.

[6] U. Kleinhans, C. Wieland, F.J. Frandsen, H. Spliethoff, Prog. Energy Combust. Sci. doi: 10.1016/j.pecs.2018.02.001

[7] P.A. Jensen, M. Stenholm, P. Hald, Energy Fuels 11 (5) (1997) 1048-1055.

[8] A. Žbogar, P.A. Jensen, F.J. Frandsen, J. Hansen, P. Glarborg, Energy Fuels 20 (2) (2006) 512519.

[9] M.S. Bashir, P.A. Jensen, F. Frandsen, S. Wedel, K. Dam-Johansen, J. Wadenbäck, Fuel Process. Technol. 97 (2012) 93-106.

[10] D. Nordgren, H. Hedman, N. Padban, D. Boström, M. Öhman, Fuel Process. Technol. 105 (2013) 
$52-58$.

[11] B.J. Skrifvars, T. Laurén, M. Hupa, R. Korbee, P. Ljung, Fuel 83 (10) (2004) 1371-1379.

[12] M.S. Bashir, P.A. Jensen, F. Frandsen, S. Wedel, K. Dam-Johansen, J. Wadenbäck, Energy Fuels 26 (4) (2012) 2317-2330.

[13] M. Theis, B.J. Skrifvars, M. Hupa, H. Tran, Fuel 85 (7-8) (2006) 1125-1130.

[14] M. Theis, B.J. Skrifvars, M. Zevenhoven, M. Hupa, H. Tran, Fuel 85 (14-15) (2006) 2002-2011.

[15] S.S. Lokare, J.D. Dunaway, D. Moulton, D. Rogers, D.R. Tree, L.L. Baxter, Energy Fuels 20 (3) (2006) 1008-1014.

[16] G. Li, S. Li, X. Xu, Q. Huang, Q. Yao, Energy Fuels 28 (1) (2014) 219-227.

[17] R. Shenassa, H. Tran, D.C.S. Kuhn, Pulp Pap. Canada 100 (10) (1999) 56-62.

[18] A.L. Robinson, H. Junker, L.L. Baxter, Energy Fuels 16 (2) (2002) 343-355.

[19] S.B. Hansen, Model for Deposition Build-up in Biomass Boilers. PhD thesis, Technical University of Denmark, Lyngby, Denmark, 2015.

[20] H. Wu, M.S. Bashir, P.A. Jensen, B. Sander, P. Glarborg, Fuel 113 (2013) 632-643.

[21] P.A. Jensen, F.J. Frandsen, J. Hansen, K. Dam-Johansen, N. Henrisken, S. Hörlyck, Energy Fuels 18 (2) (2004) 378-384.

[22] Y. Laxminarayan, Formation, Sintering and Removal of Biomass Ash Deposits. PhD thesis, Technical University of Denmark, Lyngby, Denmark, 2018.

[23] Y. Laxminarayan, P.A. Jensen, H. Wu, F.J. Frandsen, B. Sander, P. Glarborg, Energy Fuels 31 (8) (2017) 8733-8741. 
[24] H. Wu, P. Glarborg, F.J. Frandsen, K. Dam-Johansen, P.A. Jensen, Energy Fuels 25 (7) (2011) $2862-2873$.

[25] Y. Zheng, P.A. Jensen, A.D. Jensen, B. Sander, H. Junker, Fuel 86 (7-8) (2007) 1008-1020.

[26] M. Montgomery, S.A. Jensen, U. Borg, O. Biede, T. Vilhelmsen, Mater. Corros. 62 (7) (2011) 593605.

[27] M. Montgomery, A. Karlsson, O.H. Larsen, Mater. Corros. 53 (2) (2002) 121-131.

[28] C. He, G. Ahmadi, Aerosol Sci. Technol. 29 (6) (1998) 525-546.

[29] C. Thornton, Z. Ning, Powder Technol. 99 (2) (1998) 154-162.

[30] W. Ai, J.M. Kuhlman, Energy Fuels 25 (2) (2011) 708-718.

[31] C.Y. Wen, Y.H. Yu, Chem. Eng. Prog. Symp. Ser. 62 (1966) 100-111.

[32] M. Dong, S. Li, J. Xie, J. Han, Energies 6 (7), 2013, 3245-3262.

[33] L. N. Rogers, J. Reed, Journal of Physics D: Applied Physics 17 (4), 1984, 677-689.

[34] N. A. Esmen, P. Ziegler, R. Whitfield, Journal of Aerosol Science 9 (6), 1978, 547-556.

[35] H.-C. Wang, W. John, Particles on Surfaces 1, Springer, 1988, 211-224, ISBN: 978-1461595335. 


\section{List of Figures}

Figure 1. Schematic representation of the Entrained Flow Reactor.

Figure 2. Bottom chamber of the EFR. Deposits are formed on the steel tube mounted on the probe.

Figure 3. Effect of flue gas temperature and probe surface temperature on the deposit formation rate. Experiments performed with $\mathrm{K}_{2} \mathrm{Si}_{4} \mathrm{O}_{9}$ with a median particle size of $62.3 \mu \mathrm{m}$, mean gas velocity of $1 \mathrm{~m} / \mathrm{s}$, fly ash flux of $20400 \mathrm{~g} / \mathrm{m}^{2} \mathrm{~h}$ for $15 \mathrm{~min}$. Flue gas temperature during variation of probe surface temperature $=781{ }^{\circ} \mathrm{C}$. Probe surface temperature during variation of flue gas temperature $=475{ }^{\circ} \mathrm{C}$. Images captured at the end of the experiments.

Figure 4. Effect of mean gas velocity on the deposit formation rate. Experiments performed with $\mathrm{K}_{2} \mathrm{Si}_{4} \mathrm{O}_{9}$ with a median particle size of $62.3 \mu \mathrm{m}$, probe surface temperature of $475^{\circ} \mathrm{C}$, fly ash flux of $20400 \mathrm{~g} / \mathrm{m}^{2} \mathrm{~h}$ for 15 min. Images captured at the end of the experiments.

Figure 5. Effect of time and fly ash flux on the deposit formation rate. Experiments performed with $\mathrm{K}_{2} \mathrm{Si}_{4} \mathrm{O}_{9}$ with a median particle size of $62.3 \mu \mathrm{m}$, flue gas temperature of $781^{\circ} \mathrm{C}$, probe surface temperature of $475^{\circ} \mathrm{C}$, and mean gas velocity of $1 \mathrm{~m} / \mathrm{s}$. Fly ash flux during variation of time $=20400 \mathrm{~g} / \mathrm{m}^{2} \mathrm{~h}$. Time during variation of fly ash flux $=15$ min. Images captured at the end of the experiments. 


\section{Supplemental material}

Video S1. Deposit build-up in the experimental setup. Experiment performed with $\mathrm{K}_{2} \mathrm{Si}_{4} \mathrm{O}_{9}$ with a median particle size of $62.3 \mu \mathrm{m}$, a flue gas temperature of $781{ }^{\circ} \mathrm{C}$, probe surface temperature of $475^{\circ} \mathrm{C}$, mean gas velocity of $1 \mathrm{~m} / \mathrm{s}$, fly ash flux of $20400 \mathrm{~g} / \mathrm{m}^{2} \mathrm{~h}$ for $120 \mathrm{~min}$. 